\title{
PENINGKATAN AKTIVITAS BELAJAR MAHASISWA DENGAN TEKNIK MIND MAP PADA MATA KULIAH ANATOMI TUMBUHAN DI STKIP PGRI SUMATERA BARAT
}

\author{
Lince Meriko*, Febri Yanti \\ Prodi Pendidikan Biologi STKIP PGRI Sumatera Barat \\ JL. Gunung Pangilun Padang 2500 Telp. 0751-70537310
}

(Diterima Agustus 2015, disetujui Oktober 2015)

\begin{abstract}
Most students STKIP PGRI West Sumatra still have difficulty in solving problems, especially on the anatomical structure of plant tissues. This leads to low student achievement. Under these conditions, the research has been done using the Mind Map technique. The purpose of this research is to improve the students' learning activities on the subject of organ tissue structures in vegetative and generative organs of plants through the application of active learning model using Mind Map. Type of research is classroom action research (PTK) Students who become research subjects that students Session E Force 2013, which amounted to 33 people. Research carried out consisted of 2 cycles. Each cycle consists of four stages: planning, action, observation, and reflection. The results obtained after conducting this research is to increase student activity Prodi Biology Education in $2013 \mathrm{E}$ sessions on subjects anatomy of plants as a result of the implementation of the Mind Map. Comparison of the activity in the first cycle there is one indicator that achieve both criteria are indicators A.1, whereas in Cycle II there are two indicators reached excellent criteria are indicators A.1 and A.5. At the end of Cycle II students' learning activities all indicators have reached the targets set.
\end{abstract}

Keywords : Learning activity, Mind Map dan Plant Anatomy

\begin{abstract}
ABSTRAK
Sebagian besar mahasiswa STKIP PGRI Sumbar masih mengalami kesulitan dalam memecahkan masalah, terutama pada struktur anatomi jaringan tumbuhan. Hal ini menyebabkan prestasi siswa rendah. Berdasarkan hal tersebut maka telah dilakukan penelitian dengan menggunakan teknik Mind Map. Tujuan penelitian ini adalah untuk meningkatkan aktivitas belajar siswa pada pokok struktur jaringan pada organ vegetatif dan organ generatif tumbuhan melalui penerapan model pembelajaran aktif menggunakan Mind Map. Jenis penelitian yang dilakukan adalah Penelitian Tindakan Kelas (PTK) Siswa yang menjadi subjek penelitian bahwa siswa Sesi E Angkatan 2013 yang sebesar 33 orang. Penelitian yang dilakukan terdiri dari 2 siklus. Setiap siklus terdiri dari empat tahap yaitu perencanaan, tindakan, observasi, dan refleksi. Hasil yang diperoleh setelah

*Penulis korespondensi : , Lince Meriko, Febri Yanti. Prodi Pendidikan Biologi STKIP PGRI

Sumatera Barat

Email : lincemeriko@gmail.com
\end{abstract}


melakukan penelitian ini adalah peningkatan aktivitas siswa Prodi Pendidikan Biologi pada tahun 2013 sesi E pada mata pelajaran anatomi tumbuhan sebagai hasil dari penerapan Mind Map. Perbandingan aktivitas pada Siklus I ada 1 indikator yang mencapai kriteria baik yaitu indikator A.1, sedangkan pada Siklus II ada 2 indikator yang mencapai kriteria sangat baik yaitu indikator A.1, dan A.5. Pada akhir Siklus II semua indikator aktivitas belajar mahasiswa sudah mencapai target yang telah ditetapkan.

Katakunci : Aktivitas belajar, Mind Map dan Anatomi tumbuhan

\section{PENDAHULUAN}

Sebagian besar mahasiswa Prodi Pendidikan Biologi STKIP PGRI Sumatera Barat masih mengalami kesulitan dalam menyelesaikan soal anatomi tumbuhan terutama tentang struktur jaringan penyusun organ vegetatif dan generatif. Hal ini yang menyebabkan prestasi belajar mahasiswa rendah dilihat dari hasil rata-rata semester ganjil mahasiswa. Pada proses pembelajaran mahasiswa masih malu bertanya dan mengeluarkan pendapat sehingga keaktifan mahasiswa belum nampak. Hal itu dikarenakan pembelajaran anatomi tumbuhan masih berpusat pada dosen. Interaksi dan komunikasi antara mahasiswa dengan mahasiswa lainnya maupun dengan dosen belum terjalin selama proses pembelajaran karena diskusi kelompok jarang dilakukan. Dosen seharusnya menggunakan model pembelajaran yang mengajak mahasiswa untuk belajar dalam kelompok sehingga mahasiswa akan terbiasa aktif bertanya dan berpendapat. Salah satu model pembelajaran yang mendorong keaktifan, kemandirian dan tanggung jawab dalam diri mahasiswa diantaranya adalah model pembelajaran aktif menggunakan Mind Map.

Mind map adalah teknik meringkas bahan yang akan dipelajari dan memproyeksi masalah yang dihadapi ke dalam bentuk peta atau teknik grafik sehingga lebih mudah memahaminya (Buzan, 2009:5). Mind Map bertujuan membuat materi yang diberikan secara visual dan grafis yang akhirnya dapat membantu merekam, memperkuat dan mengingat kembali informasi yang telah dipelajari. Buzan (2009:3) menyatakan bahwa Mind Map adalah alat pikir organisasional yang sangat hebat. Mind Map adalah cara termudah untuk mendapatkan informasi ke dalam otak dan mengambil informasi ke luar otak. 
Kelebihan Mind Map menurut Buzan (2009:6) antara lain lebih menghemat waktu, mengaktifkan seluruh otak, menjadi lebih kreaktif, menyelesaikan masalah, memusatkan perhatian, meningkatkan daya ingat, mudah melihat gambar keseluruhan, memudahkan penambahan informasi baru, menggunakan warna, gambar, dan simbol yang lebih menarik.

Peneliti berpendapat perlunya dilakukan perbaikan proses pembelajaran pada mahasiswa Program Studi Pendidikan Biologi STKIP PGRI Sumatera Barat. Hal ini dilakukan dengan agar mahasiswa dapat ikut berperan aktif selama proses pembelajaran berlangsung. Siswa saling bertukar pendapat dalam memahami konsep jaringan penyusun organ tumbuhan serta mampu menyelesaikan soal jaringan penyusun organ tumbuhan secara berdiskusi dalam kelompok.

Tujuan penelitian tindakan kelas ini adalah untuk meningkatkan aktivitas dan hasil belajar mahasiswa pada pokok bahasan struktur jaringan penyusun organ vegetatif dan generatif tumbuhan melalui penerapan model pembelajaran aktif menggunakan Mind Map.

\section{METODE PENELITIAN}

\section{Jenis Penelitian}

Jenis Penelitian yang dilaksanakan adalah Penelitian Tindakan Kelas (PTK) atau Classroom Action Research (CAR) yang dilakukan secara kolaboratif, artinya peneliti berkolaborasi atau bekerjasama dengan tim pada mata kuliah anatomi tumbuhan. Dosen dan peneliti mendiskusikan permasalahan penelitian dan menentukan rencana tindakan. Penelitian juga dilakukan secara partisipatif, artinya peneliti dengan dibantu rekan satu tim mata kuliah yang terlibat secara langsung dalam penelitian.

Penelitian dilakukan di STKIP PGRI Sumatera Barat semester dua dengan mata kuliah Anatomi Tumbuhan. Subjek penelitian ini adalah mahasiswa semester dua yang mengikuti perkuliahan Anatomi Tumbuhan. Mahasiswa yang menjadi subjek penelitian yaitu mahasiswa Sesi E yang berjumlah 33 orang.

\section{Prosedur Penelitian}

Berdasarkan jenis penelitian yang dilaksanakan, maka prosedur dalam penelitian ini dikemas dalam bentuk siklus. Penelitian yang dilaksanakan ini terdiri 
atas dua siklus, dimana siklus dihentikan setelah melihat peningkatan aktivitas belajar mahasiswa sesuai dengan indikator yang diinginkan, dalam hal ini pemahaman konsep dan kemampuan pemecahan masalah. Secara garis besar setiap siklus terdiri atas 4 tahap, yaitu: perencanaan, tindakan, observasi/ pengamatan, dan refleksi.

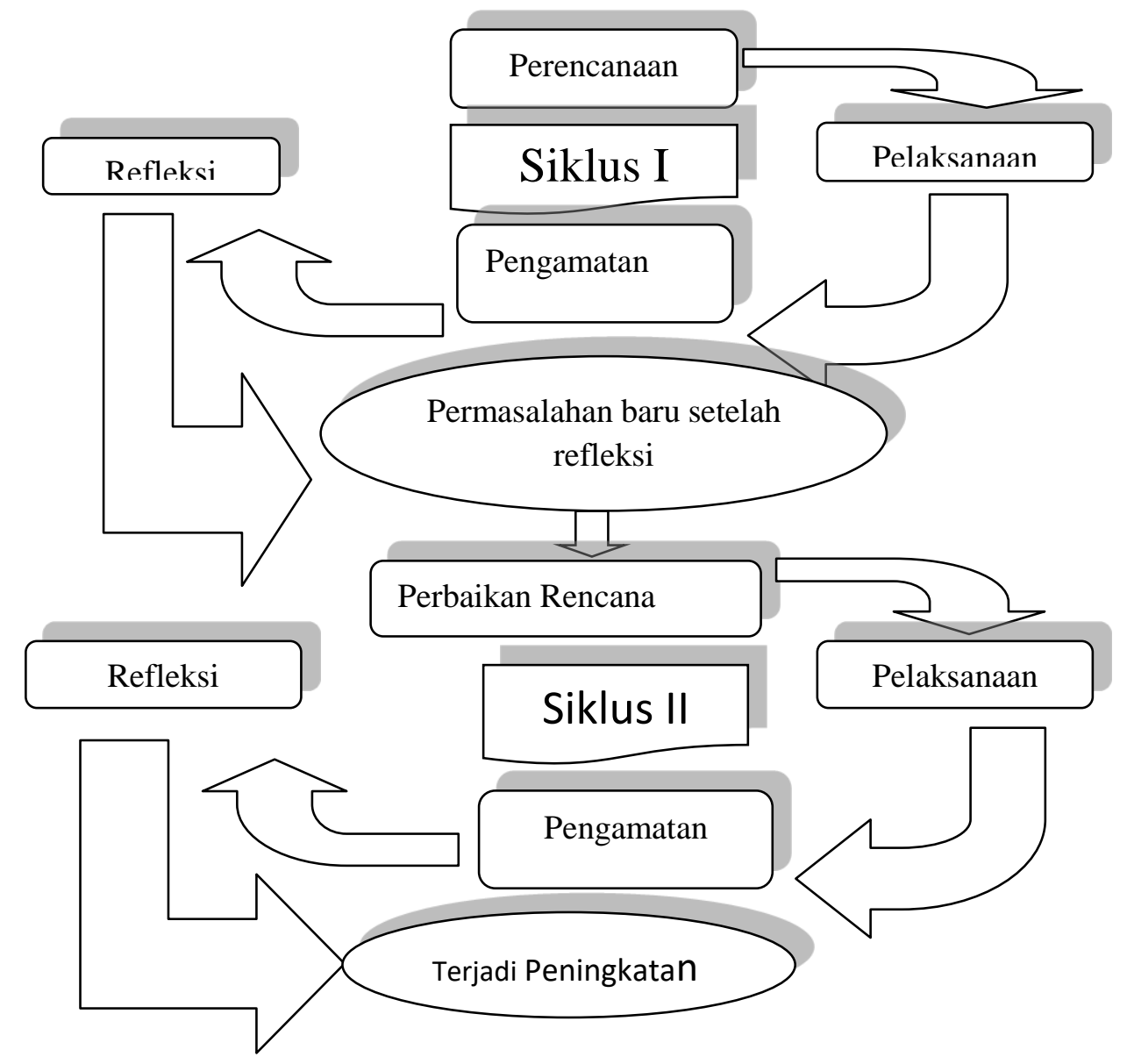

Gambar 2. Siklus Penelitian (Arikunto, 2008 : 16)

\section{Analisis Data}

\section{Aktivitas Belajar Mahasiswa}

Sudjiono (2004:43) mengungkapkan bahwa untuk data hasil pengamatan dipakai ketentuan sebagai berikut :

$$
P=\frac{f}{N} \times 100 \%
$$

Keterangan :

$\mathrm{P}=$ persentasi aktivitas yang dilakukan mahasiswa

$\mathrm{f}=$ jumlah siswa yang terlibat di setiap

$\mathrm{N}=$ jumlah mahasiswa yang hadir 
Indikator keberhasilan untuk aktivitas belajar mahasiswa secara klasikal adalah $75 \%$. Jika rata-rata aktivitas mahasiswa telah mencapai $\geq 75 \%$ berarti aktivitas mahasiswa dalam penerapan mind map sudah berhasil.

Tabel 1. Interval Aktivitas Mahasiswa

\begin{tabular}{cc}
\hline Interval Skor & Kategori \\
\hline $81-100$ & Sangat Baik \\
$61-80$ & Baik \\
$41-60$ & Cukup \\
$1-40$ & Kurang \\
\hline
\end{tabular}

\section{HASIL}

Pada penelitian ini dilakukan pengamatan aktivitas belajar mahasiswa pada setiap siklus. Penelitian tindakan kelas ini telah selesai dilaksanakan oleh peneliti pada mahasiswa Prodi. Pend. Biologi Tahun Masuk 2013 Sesi E yang mengambil mata kuliah anatomi tumbuhan dalam dua siklus, dimana siklus pertama terdiri dari tiga kali pertemuan dan siklus kedua terdiri dari dua kali pertemuan.

\section{Siklus I}

\section{Hasil Pengamatan Aktivitas Mahasiswa}

Hasil pengamatan aktivitas mahasiswa yang dilakukan selama proses perkuliahan menggunakan Mind Map dapat dilihat pada Tabel 2.

Tabel 2. Persentase Aktivitas Perkuliahan Mahasiswa Pend. Biologi Sesi E Tahun Masuk 2013 pada Siklus 1

\begin{tabular}{|c|c|c|c|c|c|}
\hline \multirow{2}{*}{ Aktivitas } & \multicolumn{3}{|c|}{ Pertemuan } & \multirow{2}{*}{$\begin{array}{l}\text { Rata-rata } \\
\text { Persentase }\end{array}$} & \multirow{2}{*}{ Kategori } \\
\hline & I & II & III & & \\
\hline A.1 & 69,69 & 87,87 & 100 & 85,85 & Baik \\
\hline A. 2 & 15,15 & 30,30 & 45,45 & 30,30 & Kurang \\
\hline A. 3 & 9,09 & 18,18 & 33,33 & 20,20 & Kurang \\
\hline A. 4 & 6,06 & 15,15 & 45,45 & 22,22 & Kurang \\
\hline A. 5 & 21,21 & 36,36 & 63,63 & 40,40 & Kurang \\
\hline
\end{tabular}

Ket : A.I.1 = Aktivitas 1 dan Siklus 1

A.1 = Mahasiswa memperhatikan penjelasan yang disampaikan dosen

A. 2 = Mahasiswa berani mengajukan pertanyaan

A.3 = Mahasiswa berani memberikan jawaban pertanyaan

A. 4 = Mahasiswa berani menjelaskan mind map di depan kelas

A.5 = Mahasiswa merangkum materi pelajaran 


\section{Siklus II}

\section{Hasil Pengamatan Aktivitas Mahasiswa}

Hasil pengamatan tentang aktivitas mahasiswa selama perkuliahan berlangsung menggunakan teknik Mind Map pada Siklus II dapat dilihat pada Tabel 3.

Tabel 3. Persentase Aktivitas Perkuliahan Mahasiswa Pend. Biologi Sesi E Tahun Masuk 2013 pada Siklus I.

\begin{tabular}{lcccl}
\hline \multirow{2}{*}{ Aktivitas } & \multicolumn{2}{c}{ Persentase Aktivitas } & \multicolumn{2}{c}{ Rata-rata } \\
Persentase & Kategori \\
\cline { 2 - 4 } & Pertemuan I & Pertemuan II & 100 & Sangat baik \\
\hline A.1 & 100 & 100 & 78,78 & Baik \\
A.2 & 75,75 & 81,81 & 75,75 & Baik \\
A.3 & 72,72 & 78,78 & 81,81 & Baik \\
A.4 & 66,67 & 96,96 & 92,41 & Sangat Baik \\
A.5 & 87,87 & 96,96 & & \\
\hline
\end{tabular}

Ket : A.II.1. = Aktivitas 1 dan Siklus II

A. 1 = Mahasiswa memperhatikan penjelasan yang disampaikan dosen

A. 2 = Mahasiswa berani mengajukan pertanyaan

A.3 = Mahasiswa berani memberikan jawaban pertanyaan

A.4 = Mahasiswa berani menjelaskan mind map di depan kelas

A.5 = Mahasiswa merangkum materi pelajaran

Tabel 3 memperlihatkan terjadinya peningkatan pada aktivitas belajar siswa. Aktivitas A.1 yaitu memperhatikan penjelasan dosen pada pertemuan I dan II dimana semua mahasiswa memperhatikan dosen akan tetapi masih ada yang melamun sehingga terlihat kurang serius dalam pelajaran.

Aktivitas A.2 dan A.3 yaitu bertanya dan menjawab pertanyaan dosen, persentasenya mengalami peningkatan. Hal ini karena mahasiswa sudah mempunyai keberanian dan tidak takut lagi untuk mengemukakan pendapatnya walaupun nanti akan diketawakan oleh teman-teman mereka.

Aktivitas A.4 yaitu mahasiswa aktif dan berani maju ke depan kelas mempresentasikan hasil Mind Map dengan persentase 81,81\%. Aktivitas A.5 yaitu membuat kesimpulan atau rangkuman dari pertemuan I dengan persentase $87,87 \%$ menjadi 96,96,2\% pada pertemuan II dengan selisih 9,09\%, walaupun tidak mencapai $100 \%$ tetapi tingkat keberhasilan sudah sesuai dengan yang diharapkan dalam penelitian ini.

Setelah mahasiswa melakukan aktivitas belajar menggunakan teknik Mind Map terlihat aktivitas belajar mahasiswa meningkat walaupun tidak semuanya. Berdasarkan penelitian yang sudah dilakukan terlihat bahwa penggunaan teknik Mind Map lebih meningkatkan keaktifan mahasiswa belajar yang selama ini hanya 
mendapat informasi dari dosen. Dengan penggunaan teknik ini mahasiswa tidak hanya mendapatkan informasi dari dosen saja tapi dari bahan yang mereka cari sendiri, selain itu kemampuan mahasiswa berpikir secara individu dan kelompok lebih meningkat.

\section{Kemajuan Penelitian Antar Siklus}

Pembelajaran dengan menggunakan teknik Mind Map dapat meningkatkan aktivitas mahasiswa, hal ini terlihat pada hasil pengamatan selama perkuliahan berlangsung, seperti pada Tabel 4.

Tabel 4. Persentase Perbandingan Aktivitas Perkuliahan Mahasiswa Pend. Biologi Sesi E Tahun Masuk 2013 pada Siklus I dan Siklus II

\begin{tabular}{lll}
\hline \multirow{2}{*}{ Aktivitas Mahasiswa } & \multicolumn{2}{l}{ Persentase Perbandingan } \\
\cline { 2 - 3 } & Siklus I & Siklus II \\
\hline A.1 & 85,85 & 100 \\
A.2 & 30,30 & 78.78 \\
A.3 & 20,20 & 75,75 \\
A.4 & 22,22 & 81,81 \\
A.5 & 40,40 & 92,41 \\
\hline
\end{tabular}

Berdasarkan Tabel 4, dapat dilihat bahwa pada Siklus I aktivitas memperhatikan penjelasan dosen (A.1) rata-rata persentase $85,85 \%$, sedangkan pada siklus II $100 \%$.

Peningkatan ini terjadi karena dosen memberikan reward kepada mahasiswa yang serius dalam belajar dan dosen memberikan sanksi kepada mahasiswa yang tidak memperhatikan pelajaran. Aktivitas aktif dalam menyampaikan Mind Map (A.4) pada Siklus I sebesar 22,22\%, sedangkan pada siklus II sebesar 96,96\% dengan selisih 74,74\%. Peningkatan ini terjadi karena dosen membimbing mahasiswa dalam membuat Mind Map, sehingga mahasiswa merasa termotivasi untuk terlibat aktif. Peningkatan ini juga dapat dilihat pada gambar di bawah ini. 


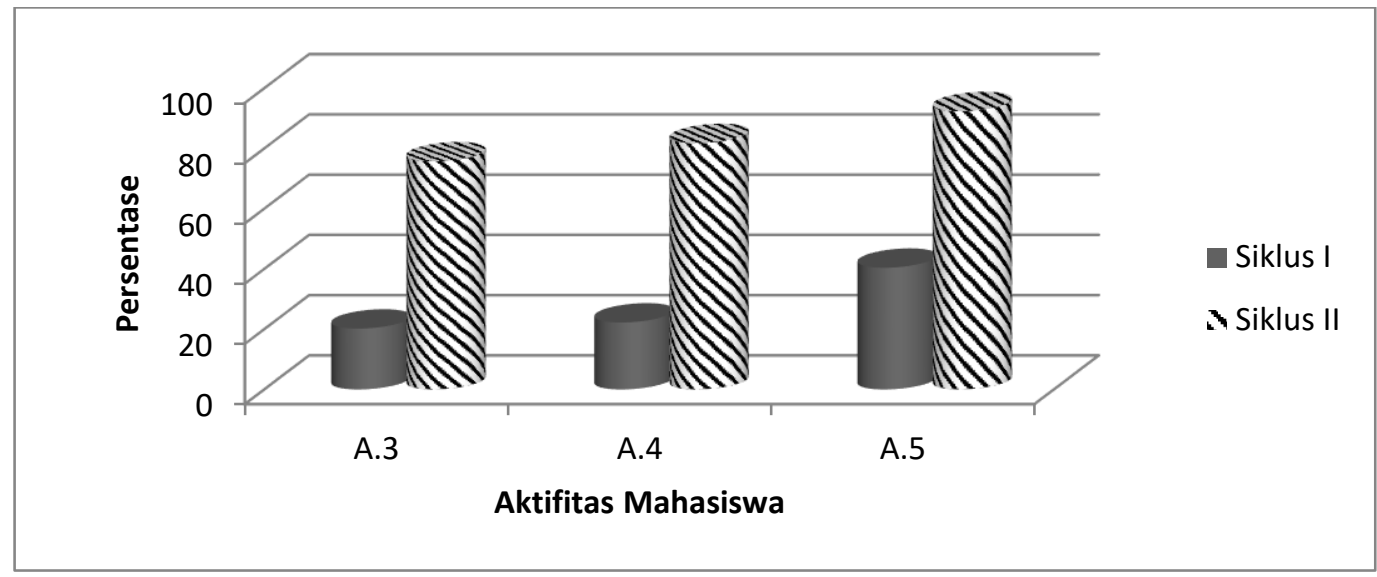

Gambar. Persentase Perbandingan Aktivitas Mahasiswa Antar Siklus

\section{PEMBAHASAN}

\section{Aktivitas Mahasiswa}

\section{Memperhatikan Penjelasan yang disampaikan Dosen}

Dari data yang diperoleh pada penelitian ini, pada Siklus I ke Siklus II dengan menggunakan teknik Mind Map terjadi peningkatan persentase aktivitas mahasiswa. Peningkatan ini terlihat pada aktivitas memperhatikan penjelasan yang disampaikan peneliti terjadi kenaikan dari $69,1 \%$ pada Siklus I menjadi 98,5\% pada siklus II. Mahasiswa sudah memahami bahwa memperhatikan penjelasan yang disampaikan dosen sangat bermanfaat dan berpengaruh terhadap proses pembelajaran yang berlangsung hingga selesai. Menurut teori belajar Ausubel bahan pelajaran yang dipelajari haruslah "bermakna" (meaning full). Pembelajaran bermakna merupakan suatu proses mengaitkan informasi baru pada konsep-konsep relevan yang terdapat dalam struktur kognitif seseorang. Struktur kognitif ialah fakta-fakta, konsep-konsep, dan generalisasi-generalisasi yang telah dipelajari dan di ingat mahasiswa.

\section{Bertanya dan Menjawab Pertanyaan}

Bertanya dan menjawab pertanyaan diobservasi pada saat dosen memberikan informasi tentang materi yang dipelajari pada saat itu dan pada saat menampilkan Mind Map di depan kelas yang dilakukan mahasiswa. Dari hasil penelitian diperoleh bahwa aktivitas mahasiswa dalam menjawab pertanyaan mengalami peningkatan, dimana pada Siklus I masih dalam kategori kurang tapi pada Siklus II mengalami peningkatan menjadi kategori cukup. Peningkatan ini terjadi karena 
diduga mahasiswa merasakan manfaat dari memperhatikan informasi yang disampaikan. Pertanyaan yang disampaikan dosen dapat merangsang mahasiswa untuk lebih termotivasi dalam memahami materi pembelajaran.

Dengan mendengarkan penjelasan dan terlibat tanya jawab mempermudah mahasiswa dalam memahami materi dan mengerjakan Mind Map. Jika ada hal-hal yang belum mereka pahami, mereka bisa menanyakan langsung pada saat itu. Hal ini juga tidak terlepas dari peran dosen dalam memfasilitasi mahasiswa untuk lebih memahami pelajaran. Dengan melakukan kegiatan bertanya, terlihat mahasiswa sudah mulai terbiasa memberikan tanggapan. Hal ini sesuai dengan yang dikemukakan oleh Nurhadi (2004:46) bahwa kegiatan bertanya sangat berguna dalam pembelajaran yang produktif.

\section{Mempresentasikan Hasil Mind Map}

Aktivitas mempresentasikan hasil Mind Map mengalami peningkatan pada dari Siklus I ke Siklus II. Pada Siklus I aktivitas mempresentasikan hasil Mind Map termasuk ke dalam kategori kurang $(20,5 \%)$ hal ini disebabkan tidak ada mahasiswa yang berani untuk mempresentasikan hasil Mind Map, kemudian peneliti berinisiatif untuk memanggil nama beberapa mahasiswa untuk mempresentasikan hasil diskusinya di depan kelas. Pada Siklus II terjadi peningkatan dengan kategori cukup $(72,1 \%)$ ini disebabkan mahasiswa sudah mulai berani mengacungkan tangan untuk mempresentasikan hasil diskusi di depan kelas. Melalui teknik Mind Map lebih berani mengemukakan ide yang ada dalam pikirannya karena mereka difasilitasi untuk berperan serta dalam pembelajaran.

\section{Membuat Kesimpulan/Rangkuman}

Aktivitas membuat kesimpulan/rangkuman mengalami peningkatan dari Siklus I masih kategori kurang (23,5\%) dan pada Siklus II mencapai kategori baik $(79,4 \%)$. Peningkatan aktivitas ini tidak terlepas dari peran dosen yang mewajibkan mahasiswa untuk membuat kesimpulan atau rangkuman pada akhir pembelajaran.

Terjadi peningkatan ini disebabkan karena mahasiswa sudah mulai merasa senang belajar menggunakan teknik Mind Map. Metode pembelajaran dengan pemberian tugas ini merupakan salah satu metode pembelajaran yang menekankan pada aktivitas dan daya pikir mahasiswa dalam menguasai materi pelajaran, guna mencapai hasil belajar yang maksimal. 
Teori Piaget menyatakan bahwa setiap individu mengalami tingkattingkat perkembangan intelektual sebagai berikut: 1) Sensori motor (0-2 tahun), 2) Pra operasional (2-7 tahun), 3) Operasional konkret (7-11 tahun), 4) Operasional formal (11 tahun ke atas). Dalam hubunganya dengan pembelajaran, teori ini mengacu kepada kegiatan pembelajaran yang harus melibatkan partisipasi peserta didik. Sehingga menurut teori ini pengetahuan tidak hanya sekedar dipindahkan secara verbal tetapi harus dikonstruksi dan direkonstruksi peserta didik. Sebagai realisasi teori ini, maka dalam kegiatan pembelajaran peserta didik harus bersifat aktif. Hal ini juga sesuai dengan pendapat Budiningsih (2005:58) yang menyatakan bahwa kegiatan belajar merupakan suatu proses pembentukan pengetahuan yang dilakukan oleh mahasiswa, dimana mahasiswa harus aktif melakukan kegiatan, aktif berpikir, menyusun konsep dan memberikan makna tentang hal-hal yang dipelajari.

Peningkatan yang terjadi pada hasil belajar menurut Slameto (1995:65) salah satunya dipengaruhi oleh faktor pendekatan belajar yang meliputi strategi dan metode yang digunakan untuk melakukan kegiatan pembelajaran. Kelebihan Mind Map adalah memberikan kesempatan kepada mahasiswa untuk berkreativitas dan terlibat secara aktif dalam berkomunikasi untuk menyelesaikan tugas-tugas mereka. Selain itu metode pembelajaran ini membantu mahasiswa untuk memahami konsep-konsep sulit dalam perkuliahan. Teknik pembelajaran ini sangat berguna untuk menumbuhkan kemampuan berpikir kritis. Dengan demikian pembelajaran menggunakan teknik Mind Map dapat meningkatkan pemahaman mahasiswa, aktivitas mahasiswa bertambah, antusias dan semangat belajar yang tinggi sehingga hasil belajar juga semakin tinggi.

\section{KESIMPULAN DAN SARAN}

\section{A. Kesimpulan}

Berdasarkan penelitian yang telah dilakukan dapat disimpulkan bahwa:

1. Telah terjadi peningkatan aktivitas belajar mahasiswa Prodi. Pend. Biologi tahun masuk 2013 sesi E pada mata kuliah anatomi tumbuhan akibat penerapan Mind Map. 
2. Perbandingan aktivitas pada Siklus I ada 1 indikator yang mencapai kriteria baik yaitu indikator A.1, sedangkan pada Siklus II ada 2 indikator yang mencapai kriteria sangat baik yaitu indikator A.1, dan A.5. Pada akhir Siklus II semua indikator aktivitas belajar mahasiswa sudah mencapai target yang telah ditetapkan.

\section{B. Saran}

Berdasarkan hasil penelitian yang telah dilakukan, peneliti menyarankan agar:

1. Tetap melakukan inovasi, variasi dalam perkuliahan sebagai upaya dalam meningkatkan aktivitas belajar mahasiswa

2. Dosen hendaknya membiasakan diri dengan menggunakan teknik Mind Map yang dapat menjadikan mahasiswa ikut berperan aktif dalam menunjang proses perkuliahan.

\section{DAFTAR PUSTAKA}

Arikunto, S. 2006. Penelitian Tindakan Kelas. Jakarta: Bumi Aksara.

Buzan, T. 2009. Buku Pintar Mind Map. Jakarta, Gramedia

Esau, K. 1976. Anatomy of Seed Plant Second Edition. Willey Eastern Limited. New Delhi.

Fidiana, I. U. 2008. Efektifitas Penggunaan Mind Map Terhadap Peningkatan Prestasi Belajar Biologi Pokok Bahasan Sistem Peredaran Darah Manusia Pada Siswa Kelas VIII Mts Negeri Ngemplak Yogyakarta[Skripsi]. Sunan Kalijaga Yogyakarta.

Hidayat, E.B. 1995. Anatomi Tumbuhan Berbiji.. Bandung : ITB

Isjoni, dkk. 2007. Pembelajran Visioner: Perpaduan Indonesia-Malaysia. Yogyakarta: Pustaka Pelajar.

Lufri 2007. Strategi Pembelajaran Biologi. Padang: UNP

Nurhadi dkk. 2004. Pembelajaran Kontekstual (Contextual Teaching and Learning/CTL) dan Penerapan dalam KBK. Malang. UNM.

Widodo, A. 2004. Constructivist Oriented Lesson The learning Environment and The Teaching Sequence.Frankfurt.Peter Lung.

Yudha, Silvia. 2006. Perbedaan Hasil Belajar Siswa yang Membuat Peta Pikiran dengan yang Menggunakan Peta Pikiran dalam Pembelajaran Biologi di SMAN 12 Padang. Padang: UNP. 